\title{
Combine Effect of Vitamin C and Cadmium on the Aminoacid Content of Citrobacter
}

\section{Freundii}

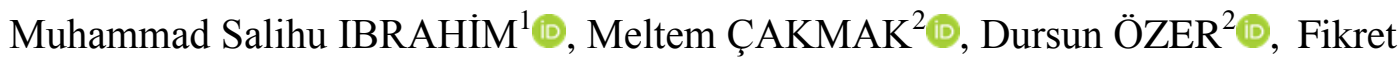 \\ KARATAS $^{1 *(\mathbb{D}, \text { Sinan SAYDAM }}{ }^{1}$
}

\author{
${ }^{1}$ Faculty of Science, Department of Chemistry, Firat University, Elazig, Turkey \\ ${ }^{2}$ Department of Chemical Engineering, Faculty of Engineering, Firat University, 23119 Elazig, Turkey \\ Geliş / Received: 04/10/2021, Kabul / Accepted: 08/12/2021
}

\begin{abstract}
In this study, Citrobacter freundii was grown in LB medium containing different concentrations of cadmium. Then, vitamin $\mathrm{C}$ were added to the medium containing cadmium and amino acids content of bacteria were determined by HPLC. It was observed that, the amount of amino acids in $C$. freundii grown in LB medium, containing 75, 100 and 125 ppm cadmium were compared with the control, the amounts of alanine, arginine, asparagine, aspartic acid, cysteine, glycine, histidine, isoleucine, leucine, lysine, phenylalanine, proline, threonine, tyrosine and valine increased $(\mathrm{p}<0.05)$, glutamic acid, glutamine, methionine, serine and tryptophan levels were decreased $\mathrm{p}<0.05$ ). With the addition of vitamin $\mathrm{C}$ to the growth medium of bacteria containing cadmium, showed that some of the amino acids concentrations increasing, rest of the amino acid studied were observed to be decreasing. From these findings, it can be said that the negative effect of cadmium on $C$. freundii is reduced by the addition of vitamin $C$ to the medium. In short vitamin $C$ reversed the effect of cadmium on the amino acid content of bacteria.
\end{abstract}

Keywords: C. freundii, Cadmium, Vitamin C, Aminoacid

C Vitamini ve Kadmiyumun Citrobacter Freundii'nin Amino Asit İçeriği Üzerindeki Birleşik Etkisi

\section{$\ddot{\mathbf{O z}}$}

Bu çalışmada, Citrobacter freundii farklı konsantrasyonlarda kadmiyum içeren LB besi yerinde üretildi. Daha sonra kadmiyum içeren besi yerine değişik konsantrasyonlarda C vitamini katılarak, her iki durumda da üretilen bakterilerdeki aminoasit miktarları HPLC ile belirlendi. Kontrol ile 75, 100 ve 125 ppm Cd içeren gruplar karşılaştırıldığında alanin, arginin, asparajin, aspartik asit, sistein, glisin, histidin, isoleusin, leusin, lisin, fenilalanin, prolin, treonin, tirozin ve valin aminoasitlerinin miktarlarında artış $(\mathrm{p}<0.05)$, glutamik asit, glutamin, metiyonin, serin ve triptofan miktarlarında ise azalma $\mathrm{p}<0.05$ ) gözlendi.

Besi ortamına ilave edilen $\mathrm{C}$ vitamini sonucunda, kadmiyumun etkisine zıt etki göstererek miktarları artan aminoasitlerde azalma, miktarları azalan aminoasitlerde ise artış gözlenmiştir. Bu bulgulardan, kadmiyumun C. freundii üzerindeki olumsuz etkisini, besi yerine katılan C vitaminin azalttığı söylenebilir.

Anahtar Kelimeler: C. freundii, Kadmiyum, C Vitamini, Aminoasitler

*Corresponding Author: fkaratas@firat.edu.tr 


\section{Introduction}

Although there are millions of living species in nature, there are common structures and characters among living things in this diversity. In addition to having many genes that humans have, microorganisms also contain some genes that humans do not have. Bacteria have the ability to reproduce in a short time by using cheap carbon and energy sources and can be modified due to their simple structure. Due to these features, they are used in the synthesis of many drugs used in the health industry by natural means, since they provide low cost (Demain \& Vaishnav, 2009). Bacteria can be grouped on the basis of cell structure, cell metabolism or cell component variations such as DNA, fatty acids, pigments, antigens and quinones. $C$. freundii is a member of the Enterobacteriaceae family which is gram-negative bacterium (O'Hara et al., 1997), that is a soil microorganism, may also be seen in other places such as food, and intestinal tracts (Wang et al., 2000). Even though $C$. freundii is a bacterial pathogen, also plays a big part in the environment's nitrogen cycle, which is responsible for environmental reduction of nitrate to nitrite (Puchenkova, 1996).

Heavy metals are toxic to living things even at low concentrations (Banfalvi, 2011). Cadmium is a heavy metal that has a substantial environmental and functional effect (Paschal et al., 2000). In biological systems, cellular organs and components such as cell membranes, mitochondria, lysosomes, endoplasmic reticulum, nuclei, certain metabolic enzymes have been documented to be impaired by heavy metals. Metal ions interact with components in cells, including DNA and nuclear proteins, causing damage to DNA and then altering conformation (Beyersmann \& Hartwig, 2008). Cadmium induces cytotoxic effects in an in vitro experiment at concentrations 0.1 to $10 \mathrm{mM}$ and the free radical damage to DNA (AlGhafari et al., 2019). In order to reduce the oxidative effect of cadmium, it has been investigated by adding substances such as vitamins $\mathrm{A}, \mathrm{E}$ and $\mathrm{C}$, which are known for their antioxidant properties. Vitamin $\mathrm{C}$ is effective in the release of some hormones in case of stress and has a strong antioxidant effect (Devaki \& Raveendran, 2017).

Amino acids is not only the building block of proteins, but also free amino acids are the potential energy-related metabolites and secondary metabolites. Considering these features, amino acids are important substances that provide cell renewal (Paul \& Driscoll, 1997; Neuberg et al., 2010). Amino acids are involved in neurotransmitter and biosynthesis processes in biological systems. For adequate production of protein in the body, it is necessary to take essential amino acids by diet (Davidson, 2019). Depending on the functions of organs in the body, amino acid concentrations can vary. Amino acid metabolism changes under various physiological and pathological conditions, leading to changes in whole body homeostasis. In recent years, the use of amino acid profiling in medical science in pathological studies and clinical diagnosis has increased the interest on amino acids $(\mathrm{Wu}$, 2013)

Since microorganisms can be reproduced easily and quickly which have many common features with other living things, it provides a great advantage in terms of medical research. For that reasons, Citrobacter freundii (NRRL B-2643) was preferred in the study to 
investigate the effect of cadmium together with vitamin $\mathrm{C}$ to counteract on the amino acids contents of $C$. freundii.

\section{Material and Method}

Citrobacter freundii (NRRL B-2643) grown in LB medium (10.0 g peptone, $5.0 \mathrm{~g}$ yeast extract, $10.0 \mathrm{~g} \mathrm{NaCl}$ per liter) was used. A stock solution of $1000 \mathrm{ppm}$ cadmium was prepared from cadmium chloride $\left(\mathrm{CdCl}_{2}\right)$. The $500 \mathrm{ppm}$ Vitamin $\mathrm{C}$ stock solution was freshly prepared every time and used.

Microorganism production was carried out in $250 \mathrm{~mL}$ flasks containing $50 \mathrm{~mL}$ broth. The following groups were studied;

1. Control: $C$. freundii was added to sterile LB medium.

2. Cadmium group: The microorganism was produced by adding different amounts of cadmium stock solution to the control, according to the desired medium concentration ( 75 , 100 and $125 \mathrm{ppm}$ ) cadmium.

3. Vitamin $\mathrm{C}$ group: The microorganism was reproduced by adding the required amount of vitamin $\mathrm{C}$ stock solution to the cadmium group according to the desired medium concentration $(25,50$ and $75 \mathrm{ppm})$.

After inoculation, it was incubated at $37^{\circ} \mathrm{C}$ with $150 \mathrm{rpm}$, for 18 hours in an orbital shaker (Selecta Rotabit). At the end of the incubation period, the concentration of bacteria was determined by reading the absorbance at $600 \mathrm{~nm}$ with UV-Visible spectrophotometer (CHEBIOS s.r.1.).

Then growth medium centrifuged at $8000 \mathrm{rpm}$, at $10{ }^{\circ} \mathrm{C}$ for 10 minutes, (Nüve NF $800 \mathrm{R}$ ) the precipitated bacteria were washed twice with distilled water, and centrifuged again and used in further processing.

\subsection{Determination of amino acids}

2.2.1. Hydrolysis: A certain weight of microorganism taken into a glass tube and $5.0 \mathrm{~mL} 6.0$ $\mathrm{N} \mathrm{HCl}$ was added and vortexed thoroughly then, samples were kept at $110{ }^{\circ} \mathrm{C}$ for 24 hours to break the peptide bonds (Elkin \& Wasynczuk, 1987). Than the samples cooled to room temperature, filtered and the filtrate volume was completed to $15 \mathrm{~mL}$ with distilled water.

2.2.2. Derivatization: Standard amino acid solutions were prepared using $0.10 \mathrm{~N} \mathrm{HCl}$ at different concentrations between 1.0 to $5.0 \mu \mathrm{g} / \mathrm{mL}$. $50 \mu \mathrm{L}$ Standard amino acid solutions or hydrolysed samples transferred to $5.0 \mathrm{~mL}$ glass tubes and dried under vacuum at $65^{\circ} \mathrm{C}$. Then $50 \mu \mathrm{L}$ of reagent 1 [(2: 2: 1 mixture of ethanol: water: Triethylamine (TEA) (v/v)] was added vortexed and dried again under vacuum at $65{ }^{\circ} \mathrm{C}$. To the dried samples $50 \mu \mathrm{L}$ of reagent 2 [7: 1: 1: 1 mixture of ethanol: water: TEA: phenyl isothiocyanate (PITC) (v/v)] was added, vortexed and left at room temperature in the dark for 30 minutes to complex formation. At the end of this period, the samples were dried again under vacuum at $35{ }^{\circ} \mathrm{C}$ (Kwanyuen \& 
Burton, 2010). $1.0 \mathrm{~mL}$ Mobile phase A and acetonitrile (ACN) mixture (8: $2 \mathrm{v} / \mathrm{v})$ was added to each dried sample, vortexed and the samples were taken into HPLC vials for analysis.

\subsubsection{Chromatographic procedure for amino acid analysis}

Amino acid analysis was performed by using HPLC with modified Elkin \& Wasynczuk (1987) and Kwanyuen \& Burton (2010) methods. Nucleodur 100-5 C18 column (250x4.6 $\mathrm{mm}, 5 \mu \mathrm{m})$ was used. The analyses were carried out by applying the gradient program at 40 ${ }^{\circ} \mathrm{C}$. The mobile phase consists of eluent $\mathrm{A}$ and eluent $\mathrm{B}$ mixture with a flow rate of 0.8 $\mathrm{mL} / \mathrm{min}$ and phenylthiocarbamyl-amino acids complexes were measured at $254 \mathrm{~nm}$ (Table 1). Eluent $\mathrm{A}$ is $0.07 \mathrm{M} \mathrm{CH}_{3} \mathrm{COONa} \cdot 3 \mathrm{H}_{2} \mathrm{O}\left(\mathrm{pH}=6.4\right.$ with $\left.\mathrm{CH}_{3} \mathrm{COOH}\right)$ and eluent $\mathrm{B}$ is a mixture of $\mathrm{ACN}$ and water $(60: 40 \mathrm{v} / \mathrm{v})$

Table 1. Gradient program used for the separation of Phenylthiocarbamyl-amino acids

\begin{tabular}{llll}
$\begin{array}{l}\text { Time } \\
\text { (minute) }\end{array}$ & $\begin{array}{l}\text { Flow rate } \\
(\mathrm{mL} / \mathrm{min})\end{array}$ & $\begin{array}{l}\% \\
\text { Eluent A }\end{array}$ & $\begin{array}{l}\% \\
\text { Eluent B }\end{array}$ \\
\hline 0.01 & 0.8 & 90 & 10 \\
12.00 & 0.8 & 70 & 30 \\
16.00 & 0.8 & 65 & 35 \\
16.01 & 0.8 & 50 & 50 \\
25.00 & 0.8 & 100 & 0 \\
30.00 & 0.8 & 50 & 50 \\
30.01 & 0.8 & 10 & 90 \\
35.00 & 0.8 & 10 & 902 \\
\hline
\end{tabular}

\subsection{Statistical Analysis}

All measurements were triplicated and mean \pm standard deviation was determined. The results were subjected to Variance Analysis by SPSS 10.0 for Windows.

The effect of cadmium is significant compared to the control $\mathrm{p}<0.05)$ a, The effect of vitamin $\mathrm{C}$ is significant compared to $0 \mathrm{ppm}$ vitamin $\mathrm{C}(\mathrm{p}<0.05) \mathbf{b}$, The effect of vitamin $\mathrm{C}$ is insignificant compared to $0 \mathrm{ppm}$ vitamin $\mathrm{C}(\mathrm{p}>0.05)$ c.

\section{Results and Discussion}

It is well known that, function of living organism impaired by heavy metals. With the advancement of technology, environment is polluted by the heavy metals and especially the water resources. After passing through the cell membrane, heavy metals accumulated in the metabolism of the cell or play a negative role in the cell content by forming complexes with various components in the cell (Husein, 2012). Amino acids are highly important molecules for all living cells. They are the building blocks of protein and intermediates in metabolic pathways. They also play a pivotal role in metabolism, regulating gene expression, immunity, signal transduction, anti-oxidative responses, growth and cell survival (Wu, 2010). 
In a preliminary study, microorganism growth was not affected up to $40 \mathrm{ppm} \mathrm{Cd}$, and there was no significant growth over $150 \mathrm{ppm} \mathrm{Cd}$, therefore 75, 100 and $125 \mathrm{ppm} \mathrm{Cd}$ concentrations were chosen. In addition, less than $25 \mathrm{ppm}$ vitamin $\mathrm{C}$ have no significant effect on the microorganism growth, for that reason we have chosen vitamin $\mathrm{C}$ concentration 25,50 and $75 \mathrm{ppm}$.

The changes in the amino acid content of $C$. freundii depend on the different concentrations of cadmium and vitamin $\mathrm{C}$ are given in Figure 1-20.

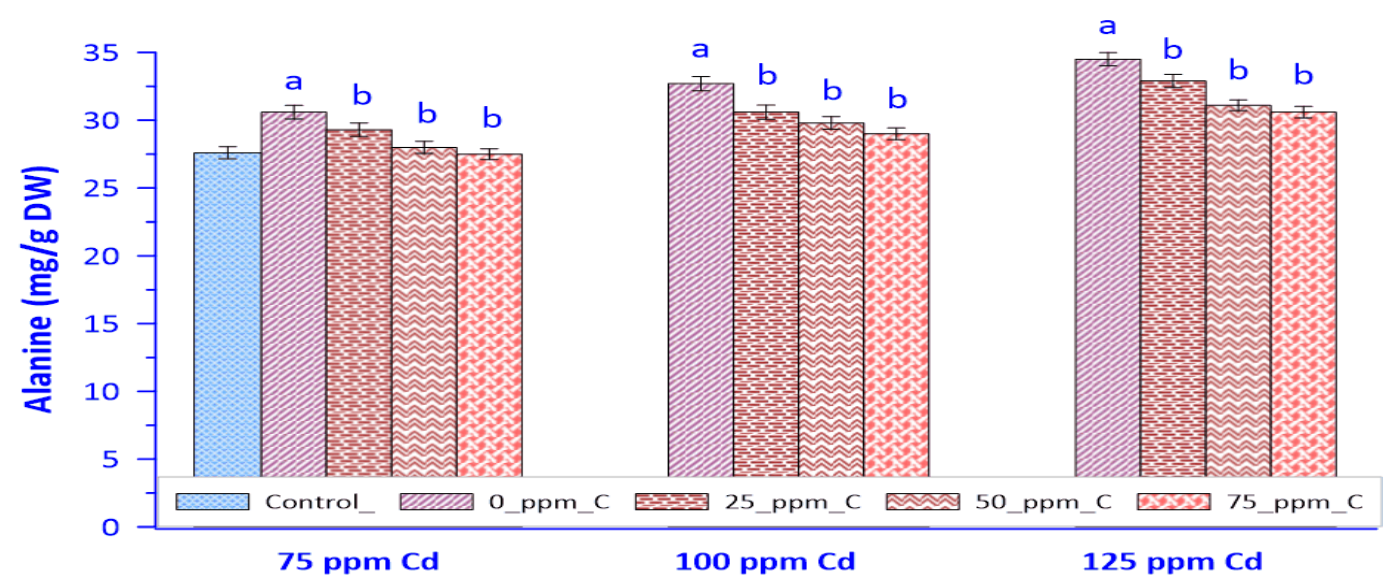

Figure 1. Effect of cadmium and vitamin $\mathrm{C}$ on the level of alanine in C. freundii

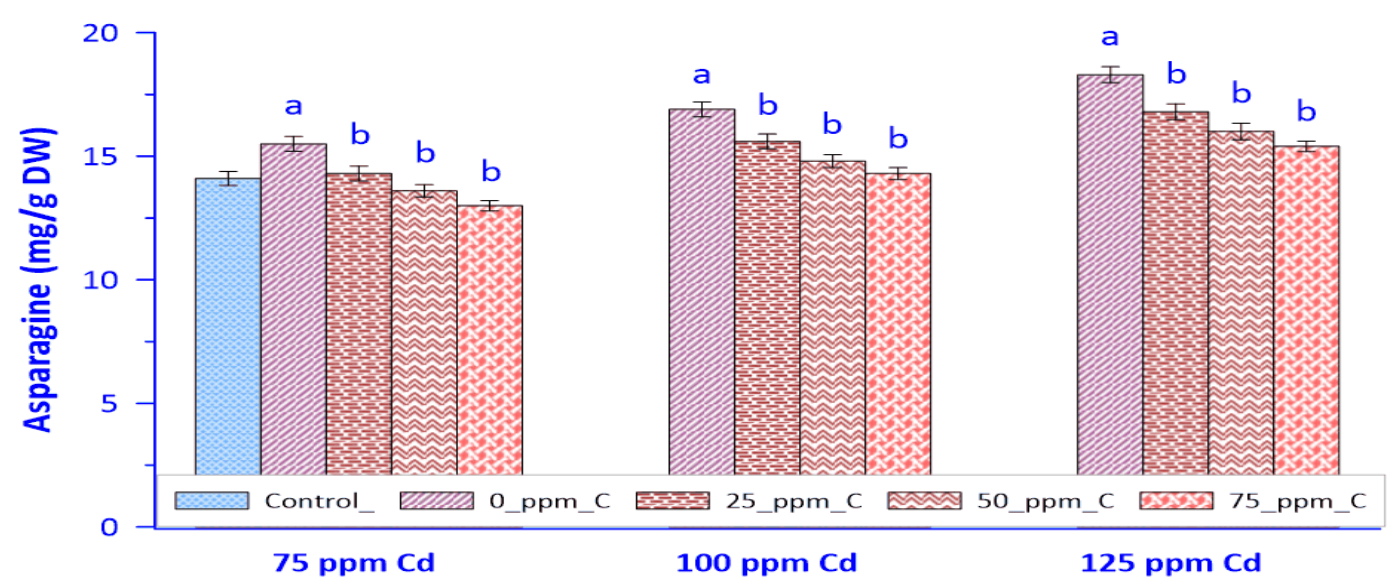

Figure 2. Effect of cadmium and vitamin $\mathrm{C}$ on the level of asparagine in $C$. freundii 


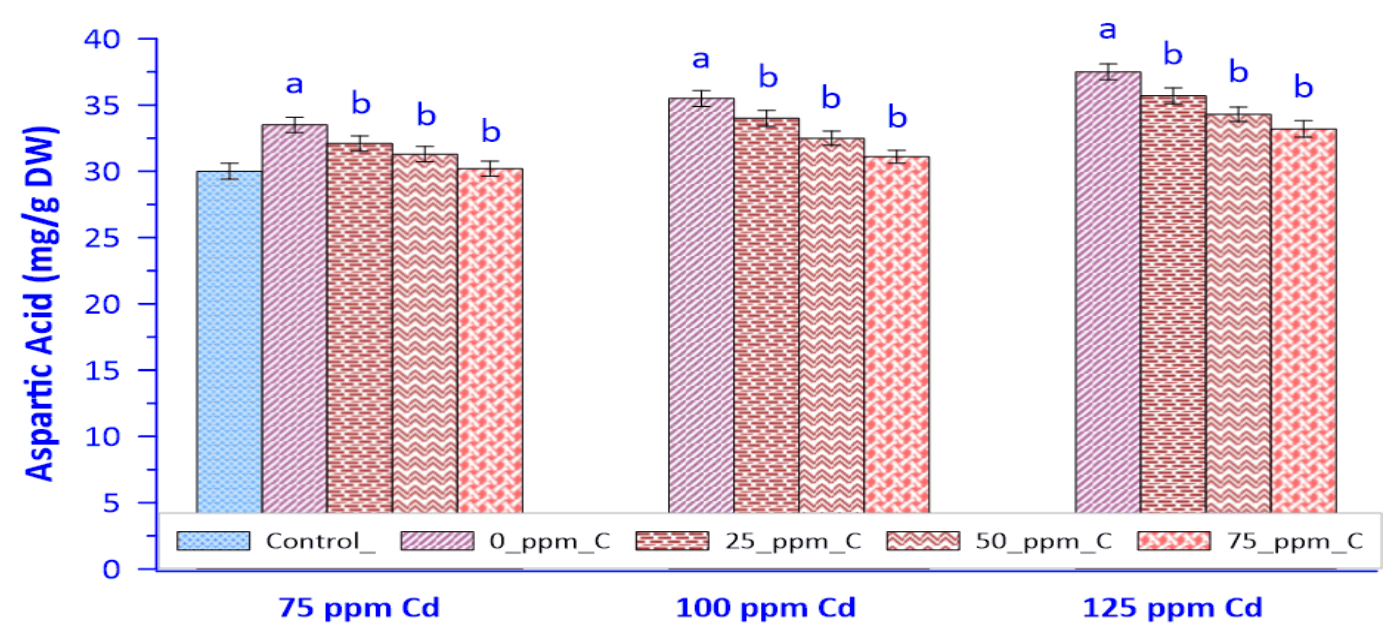

Figure 3. Effect of cadmium and vitamin $\mathrm{C}$ on the level of aspartic acid in $C$. freundii

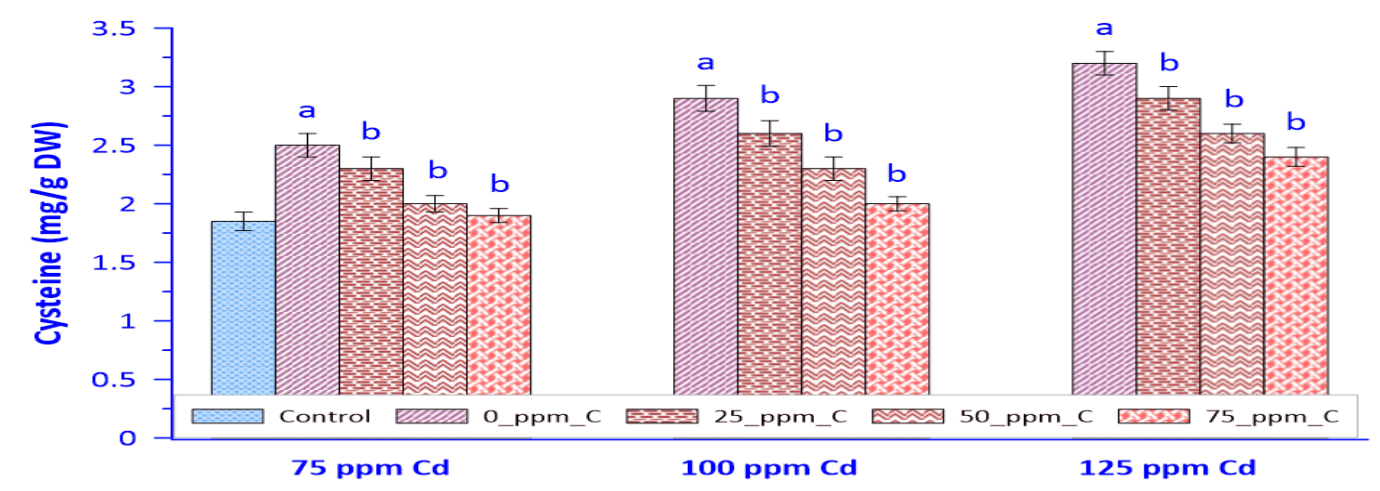

Figure 4. Effect of cadmium and vitamin $\mathrm{C}$ on the level of cysteine in C. freundii

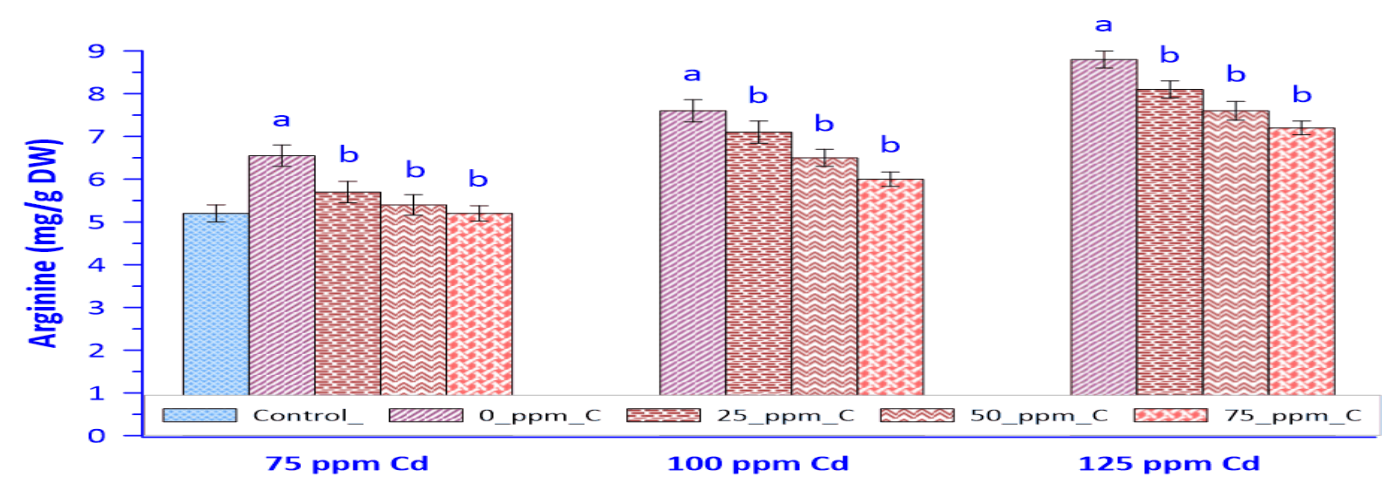

Figure 5. Effect of cadmium and vitamin $\mathrm{C}$ on the level of arginine in C. freundii 


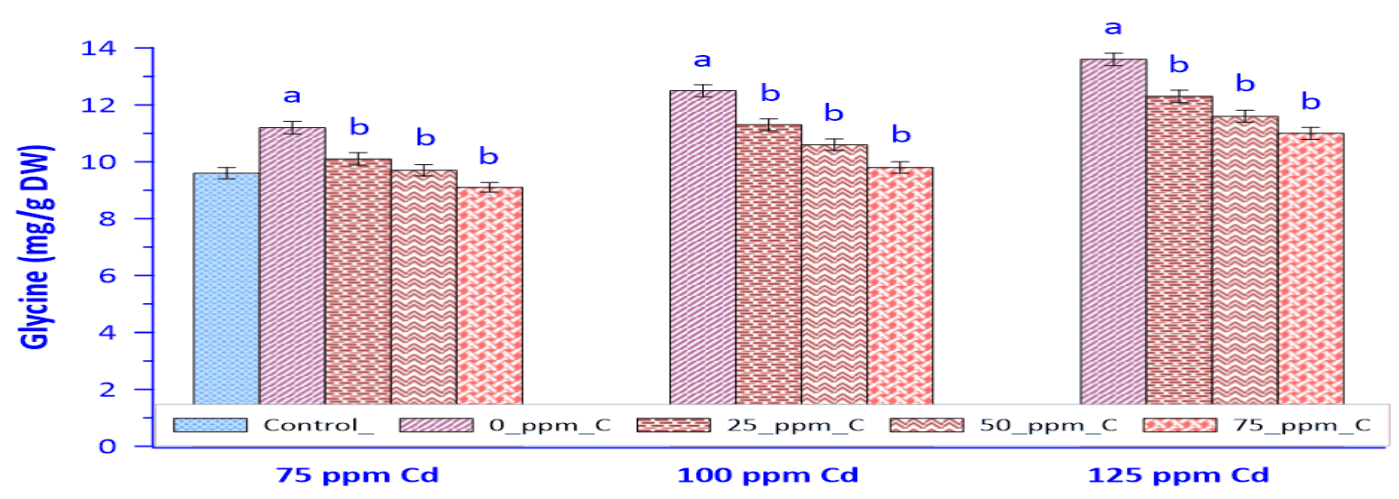

Figure 6. Effect of cadmium and vitamin $\mathrm{C}$ on the level of glycine in $C$. freundii

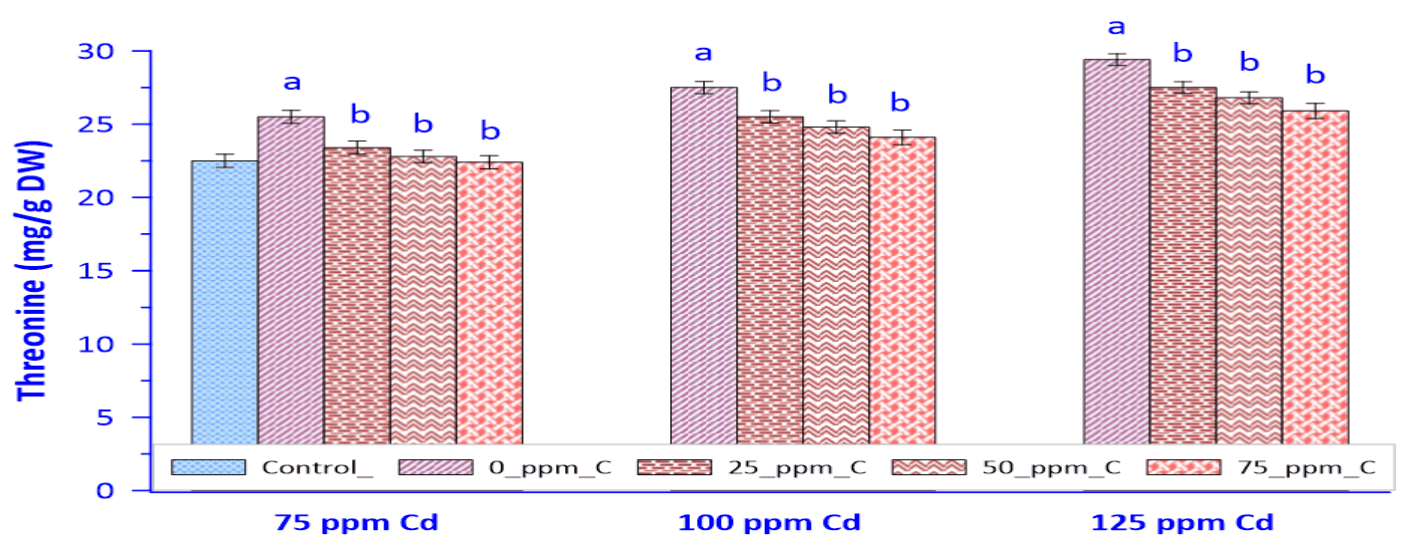

Figure 7. Effect of cadmium and vitamin $\mathrm{C}$ on the level of threonine in $C$. freundii

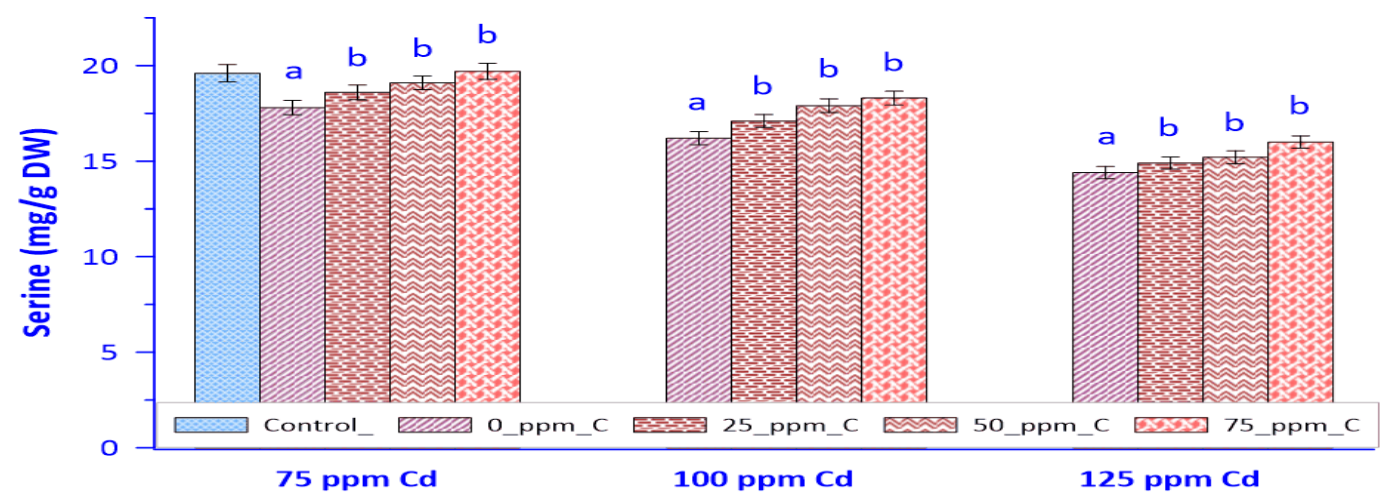

Figure 8. Effect of cadmium and vitamin $C$ on the level of serine in $C$. freundii

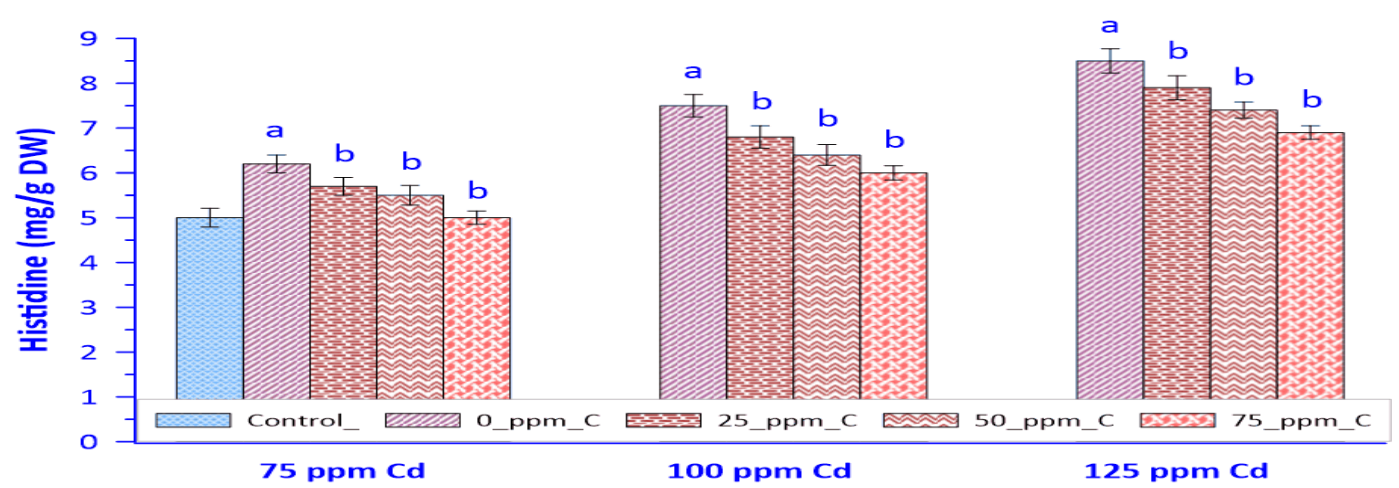

Figure 9. Effect of cadmium and vitamin $\mathrm{C}$ on the level of histidine in $C$. freundii 


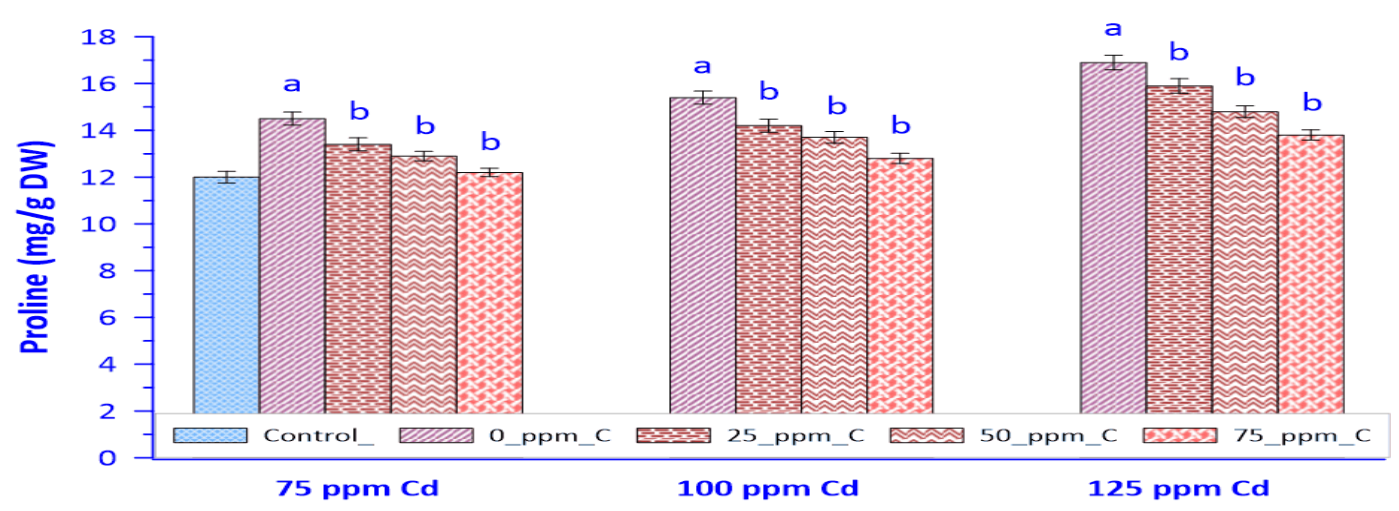

Figure 10. Effect of cadmium and vitamin $\mathrm{C}$ on the level of proline in $C$. freundii

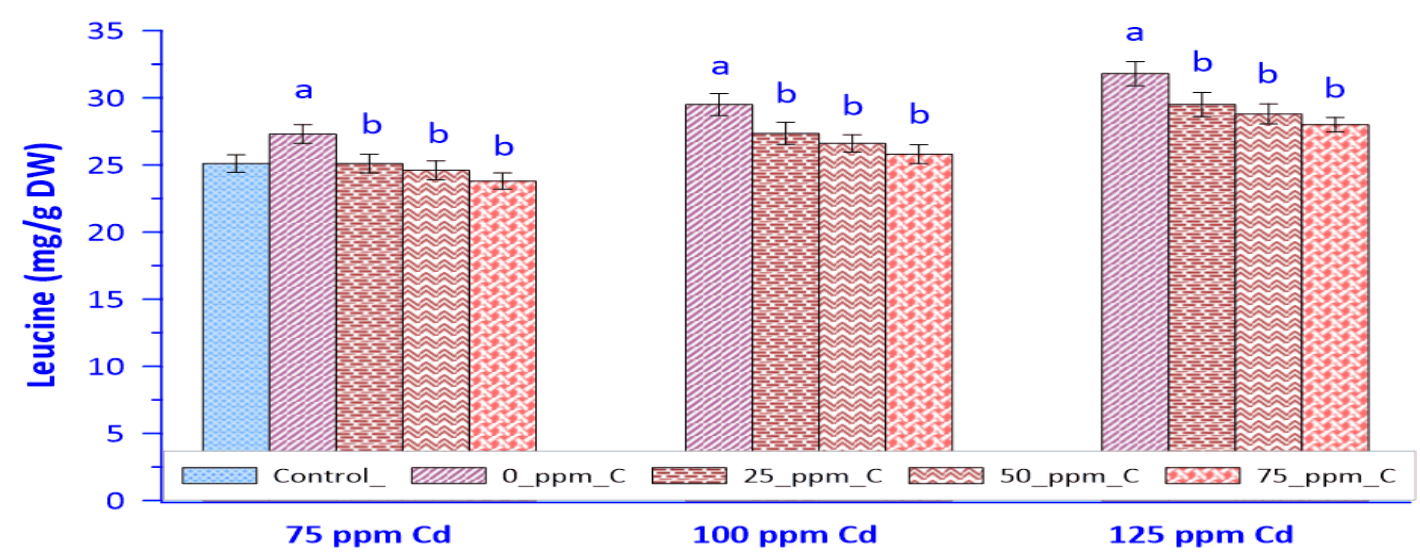

Figure 11. Effect of cadmium and vitamin $\mathrm{C}$ on the level of leucine in $C$. freundii

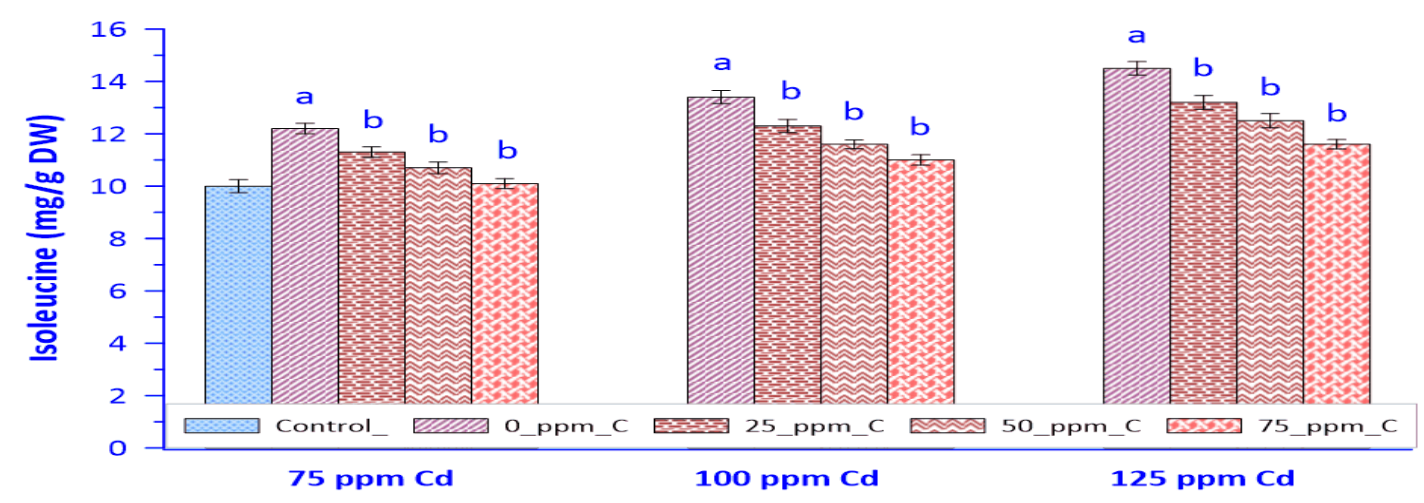

Figure 12. Effect of cadmium and vitamin $C$ on the level of isoleucine in C. freundii

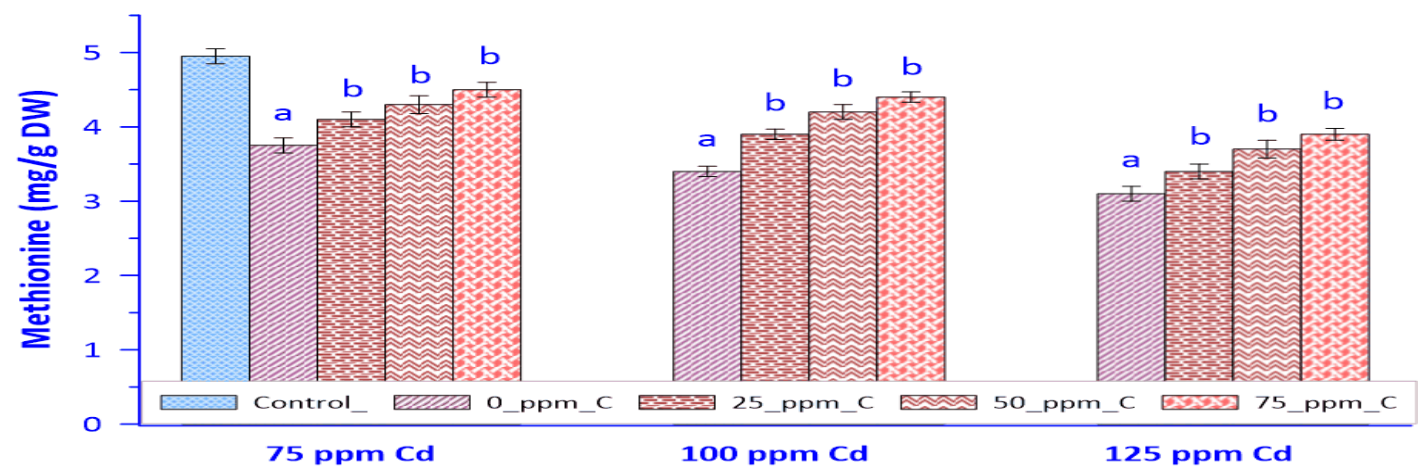

Figure 13. Effect of cadmium and vitamin $\mathrm{C}$ on the level of methionine in $C$. freundii 


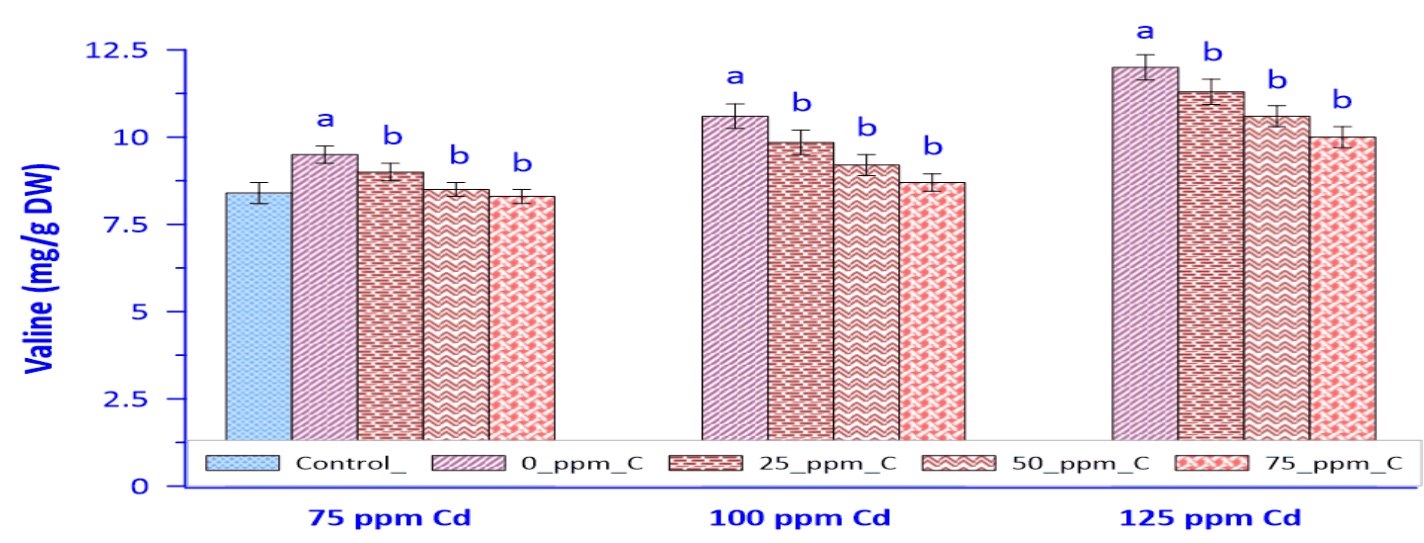

Figure 14. Effect of cadmium and vitamin $C$ on the level of valine in $C$. freundii

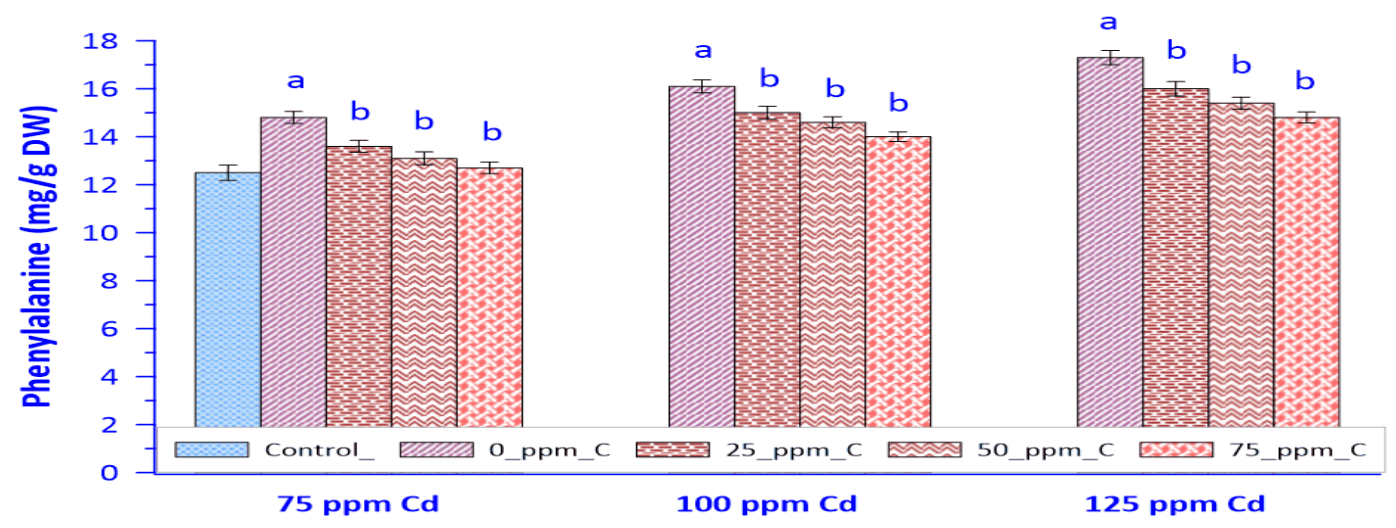

Figure 15. Effect of cadmium and vitamin $\mathrm{C}$ on the level of phenylalanine in $C$. freundii

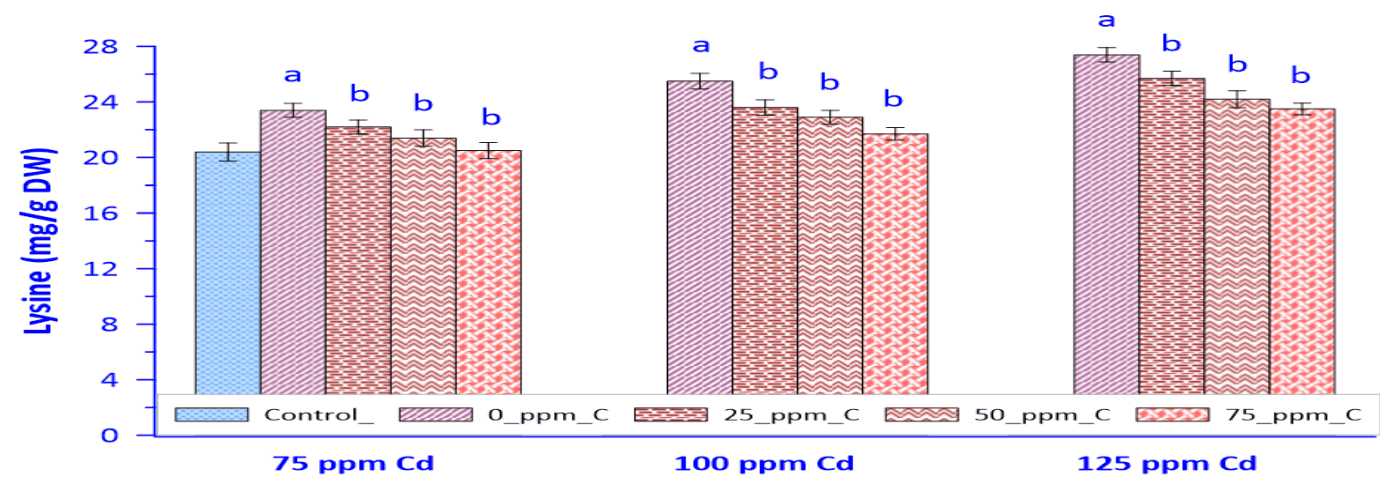

Figure 16. Effect of cadmium and vitamin $C$ on the level of lysine in $C$. freundii

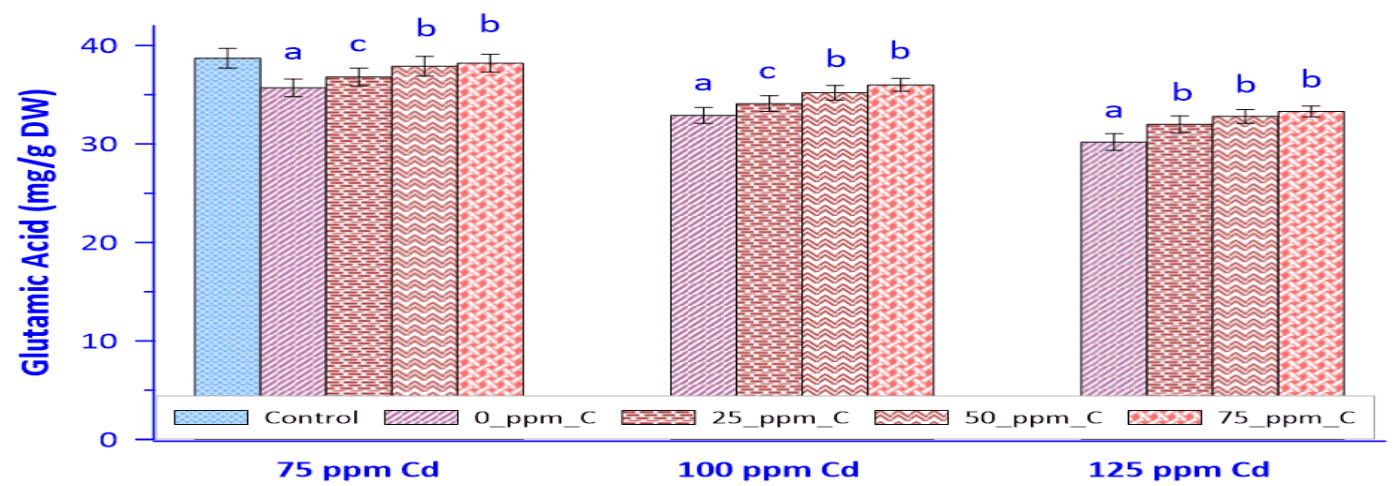

Figure 17. Effect of cadmium and vitamin $\mathrm{C}$ on the level of glutamic acid in $C$. freundii 


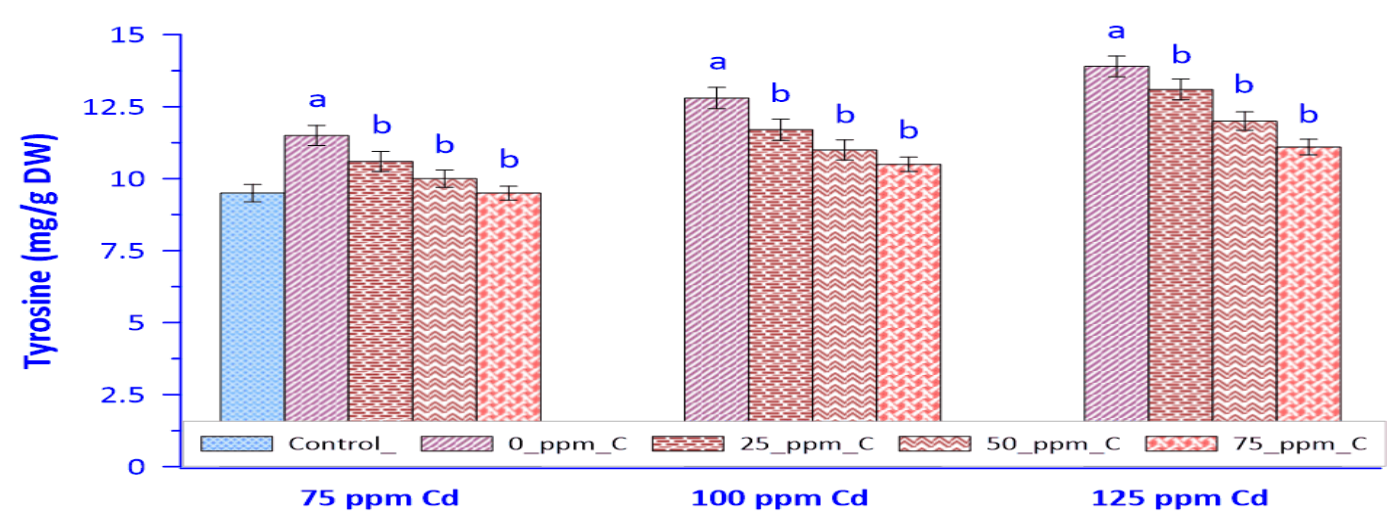

Figure 18. Effect of cadmium and vitamin $\mathrm{C}$ on the level of tyrosine in C. freundii

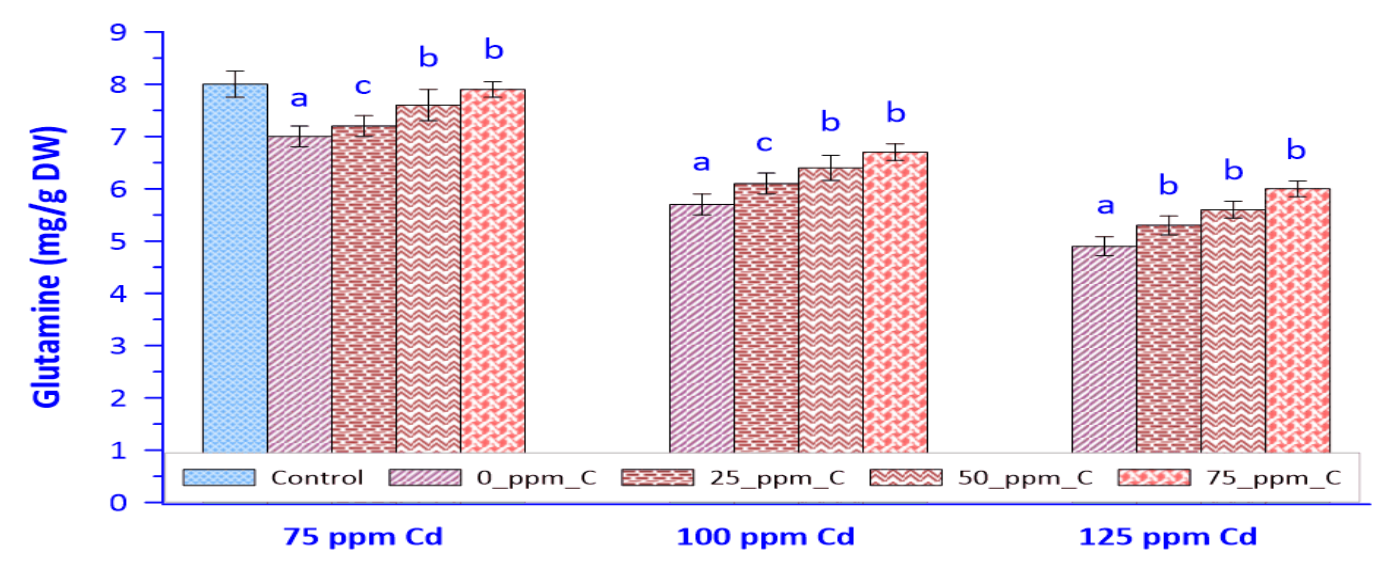

Figure 19. Effect of cadmium and vitamin $C$ on the level of glutamine in C. freundii

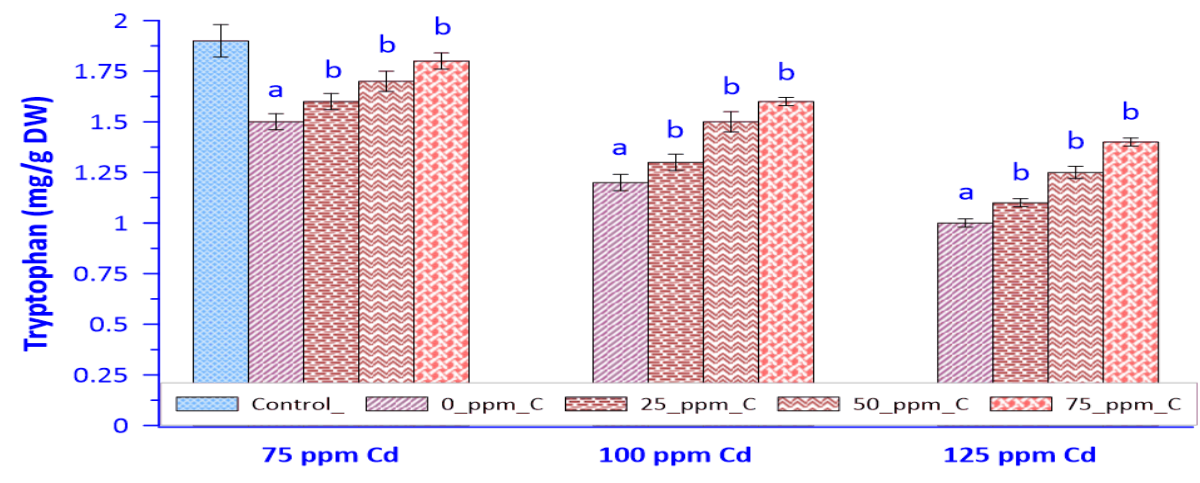

Figure 20. Effect of cadmium and vitamin $\mathrm{C}$ on the level of tryptophan in C. freundii

As seen from the figures, the amino acid with the highest concentration is glutamic acid $(38.70 \pm 1.0 \mathrm{mg} / \mathrm{g} \mathrm{dw})$ and the amino acid with the lowest concentration is tryptophan $(1.90 \pm$ $0.08 \mathrm{mg} / \mathrm{g} \mathrm{dw}$ ). The order from highest to lowest concentration is glutamic acid > aspartic acid $>$ alanine $>$ leucine $>$ threonine $>$ lysine $>$ serine $>$ asparagine $>$ phenylalanine $>$ proline $>$ 1soleucine $>$ glycine $>$ tyrosine $>$ valine $>$ glutamine $>$ arginine $>$ histidine $>$ methionine $>$ cysteine $>$ tryptophan. 
Obtained results indicate that the amount of glutamic acid, glycine, serine, histidine, valine, aspartic acid, proline, tyrosine, alanine, methionine and phenylalanine to be $38.70 \pm 1.00,9.60$ $\pm 0.20,19.60 \pm 0.45,5.00 \pm 0.21,8.40 \pm 0.30,30.00 \pm 0,60,12.00 \pm 0.25,9.50 \pm 0.30,27.60$ $\pm 0.45,4.95 \pm 0.10$ and $12.50 \pm 0.32 \mathrm{mg} / \mathrm{g} \mathrm{dw}$ in $C$. freundii respectively, while that of E.coli was reported to be $35.00 \pm 3.02,94.00 \pm 4.00,1.10 \pm 0.04,3.00 \pm 1.40,1.80 \pm 1.30,51.00 \pm$ $3.70,1.60 \pm 0.1,0.1 \pm 0.2,13.00 \pm 0.50,4.30 \pm 0.40$ and $0.40 \pm 0.02 \mathrm{nmoles} / \mathrm{mg}$ dry cell mass respectively (Alreshidi et al., 2019).

When compared with control, addition of 75, 100 and $125 \mathrm{ppm}$ cadmium significantly increase the level of alanine, arginine, asparagine, aspartic acid, cysteine, glycine, histidine, isoleucine, leucine, lysine, phenylalanine, proline, threonine, tyrosine and valine $(p<0.05)$, while glutamic acid, glutamine, methionine, serine and tryptophan shows a significant decrease when compared with control $(\mathrm{p}<0.05)$ (Figure 1-20).

Cadmium affects the amino acid metabolism of all living cells. Amino acids have important functions such as metal binding, antioxidant defence and signalling in cells during heavy metal stress (Xu et al., 2012a). Zemanova et al. (2017) reported that the amount of amino acids contends in tissues changes with the stresses caused by cadmium.

Alanine is involved in many events such as regulation of intracellular $\mathrm{pH}$, reduction and regulation of nitrogen-dependent metabolic events during stress. The increased alanine due to stress plays an important role in the defence system (Kalefetoğlu \& Ekmekçi, 2005). Asparagine promotes nitrogen accumulation and plays an important role in regulating the sugar balance in the cell (Haroun et al., 2010). Aspartic acid is an important amino acid in the tricarboxylic acid cycle, triggers metabolic events and the production of signal amino acids by activating defence systems, and its amount increases under stress conditions (Sanchez et al., 1998). Cysteine plays a role in the development of anabolic and catabolic events in living organisms, acts as a stimulus in response to mechanisms under stress conditions, and increases the amount during stress (Kalefetoğlu \& Ekmekçi, 2005). Arginine is nitrogen source in the cell and acts as a precursor for the biosynthesis of polyamines and nitric oxide, which are necessary for physiological and biochemical processes, growth, development, and adaptation to stress conditions (Yang \& Gao, 2007). Glycine is synthesized under stress conditions and accumulates in tissue. It is an amino acid that acts directly or indirectly to protect plasma membranes in reducing the effect of oxygen-dependent free radicals (Chen \& Murata, 2008). Threonine is the basic part of proteins such as collagen and elastin, has very important roles in fat metabolism and immune system, and also helps in the synthesis of glycine and serine. Glycine, threonine and arginine are amino acids whose amounts increase under stress conditions (Olgun et al., 2016). Histidine is a stress response amino acid that indicates the cell's response to abiotic stresses, and the amount of histidine increases at the time of stress (Fersht, 1999). Polypeptides and proteins containing high levels of proline, glycine, leucine and methionine play an important role in cell wall growth and stress adaptation (Pavlíková et al., 2008), while leucine, isoleucine and valine amino acids play an important role during osmotic stress in the cell (Joshi et al., 2010). Phenylalanine plays an important role in catabolic events that require carbon and nitrogen and is necessary for the 
defence mechanisms (Tohge et al., 2013). Lysine is used to increase the resistance of the cell against abiotic and biotic stresses and produce glutamic acid. The amount of lysine and phenylalanine increases due to stress (Azevedo \& Lea, 2001). Tyrosine plays a triggering and catalysing role in the formation of metabolic events related to the defence of the organism against stress conditions (Ghelis, 2011). Valine and leucine play important roles in preventing the deterioration of the structure of growth-related enzymes under stress conditions and reducing the amount of free oxygen-based radicals in the cell. Therefore, amount of these two amino acids increase due to the stress (Singhl \& Shaner, 1995). Glutamic acid is effective in the carbon and nitrogen cycle of metabolism and is important for proline biosynthesis. While the amount of glutamic acid decreases during stress, the amount of proline increases (Forde $\&$ Lea, 2007). Glutamine is decreases under stress conditions and it acts as a marker that regulates nitrogen metabolism in the cell (Miflin \& Habash, 2002). Serine has a fundamental role in metabolism and signalling in living organisms, and its amount decreases during stress (Ros et al., 2014). Tryptophan plays an important role in regulating cell development and defence responses. It is reported that the amount of tryptophan increases under stress conditions (Zemanova et al., 2017). On the other hand, Olgun et al. (2016) reported that, stress induced by KI, caused to decrease tryptophan concentration in some wheat varieties which is compatible with our result. Our all the findings except tryptophan (Zemanova et al., 2017) are compatible with the literature cited.

Vitamin $\mathrm{C}$ is an essential micronutrient required for various biochemical and physiological processes in the body. Vitamin $\mathrm{C}$ has a role in tissue repair, protein formation, inactivation of toxic metals and protection of other vitamins (such as A and E), DNA from the harmful effects of oxidation (Hamza, 2017). In a study conducted by Sahiti et al. (2020), it was reported that vitamin $\mathrm{C}$ reduced the heavy metal accumulation in the tissues. Due to these properties of vitamin $C$, various concentrations of vitamin $C(25,50$ and $75 \mathrm{ppm})$ were added to the LB medium containing cadmium, in order to reduce the negative of cadmium.

When compared with 0 ppm vitamin $\mathrm{C}$ group, addition of 25,50 and $75 \mathrm{ppm}$ vitamin $\mathrm{C}$ significantly decrease the level of alanine, arginine, asparagine, aspartic acid, cysteine, glycine, histidine, isoleucine, leucine, lysine, phenylalanine, proline, threonine, tyrosine and valine $(\mathrm{p}<0.05)$, while methionine, glutamic acid, glutamine, serine and tryptophan shows a significant increase when compared with $0 \mathrm{ppm}$ vitamin $\mathrm{C}$ group $(\mathrm{p}<0.05)$. However, the decrease in the amount of $25 \mathrm{ppm}$ vitamin $\mathrm{C}$, glutamic acid and glutamine added to the medium containing 75 and 100 ppm Cd is insignificant (p>0.05) (Figure 1-20).

It can be said that addition of vitamin $\mathrm{C}$ to the $\mathrm{Cd}$-containing medium reduces the negative effect of $\mathrm{Cd}$ partially, since it brings both the amino acid content and microorganism concentration closer to the control value (Figure 1-20).

\section{Conclusion}

Increased concentration of cadmium in LB medium, caused to decrease some amino acids concentration, while the rest of the amino acid concentration studied were increased. Opposite the effects were obtained when vitamin $\mathrm{C}$ was introduced to the growth medium of bacteria 
containing different amount of $\mathrm{Cd}$. In short vitamin $\mathrm{C}$ reversed the effect of $\mathrm{Cd}$ on the amino acid content of bacteria.

\section{References}

Al-Ghafari, A., Elmorsy, E., Fikry, E., Alrowaili, M., Carter, W.G., \& Mukhopadhyay, P. 2019. "The heavy metals lead and cadmium are cytotoxic to human bone osteoblasts via induction of redox stress". Plos One, 14(11), e0225341

Alreshidi, M.M., Dunstan, R.H., Macdonald, M.M., Smith, N.D., Gottfries, J., \& Roberts, T.K. 2019. "Amino acids and proteomic acclimation of Staphylococcus aureus when incubated in a defined minimal medium supplemented with 5\% sodium chloride". Microbiologyopen, C 8, e00772.

Azevedo, R.A., \& Lea, P.J. 2001. "Lysine metabolism in higher plants". Amino Acids, 20(3), 261-279.

Banfalvi, G. 2011. "Cellular Effects of Heavy Metals". Netherlands, London, New York: Springer. ISBN 978-94-007-0428-2

Beyersmann, D., \& Hartwig, A. 2008. "Carcinogenic metal compounds: recent insight into molecular and cellular mechanisms". Archives of toxicology, 82, 493-51

Chen, T.H., \& Murata, N. 2008. "Glycinebetaine: an effective protectant against abiotic stress in plants". Trends of Plant Science, 13(9), 499-505.

Davidson, J.A. 2019. "Amino Acids in Life: A Prebiotic Division of Labor". J Mol Evol. https://doi.org/10.1007/s00239-018-9879-z.

Demain, A.L., \& Vaishnav, P. 2009. "Production of recombinant proteins by microbes and higher organisms". Biotechnol Adv, 27: 297-306.

Devaki, S.J., \& Raveendran, R.L. 2017. "Vitamin C: Sources, Functions, Sensing and Analysis". INTECH http://dx.doi.org/10.5772/intechopen.70162

Elkin, R.G., \& Wasynczuk, A.M. 1987. "Amino Acid Analysis of Feedstuff Hydrolysates by Precolumn Derivatization with Phenylisothiocyanate and Reversed-Phase High-Performance Liquid Chromatography". Cereal Chemistry 64(4), 226-229.

Fersht, A. 1999. "Structure and Mechanism in Protein Science". W.H. Freeman and Company; New York.

Forde, B.G., \& Lea, J.F. 2007. "Glutamate in plants: metabolism, regulation, and signalling". Journal of Experimental Botany. 58(9), 2339-2358

Ghelis, T. 2011. "Signal processing by protein tyrosine phosphorylation in plants". Plant Signaling \& Behavior, 6(7), 942-951. 
Hamza, Amal H. 2017. "Vitamin C || Vitamin C: Sources, Functions, Sensing and Analysis". 10.5772/66058(Chapter 1), DOI:10.5772/intechopen.7016

Haroun, S.A., Shukry, W.M., \& El-Sawy, O. 2010. "Effect of asparagine or glutamine on growth and metabolic changes in phaseolus vulgaris under in vitro conditions". Bioscience Research, 7(1), 1-21.

Husein, A.S. 2012. "Genetic Relationship Between Heavy metals Resistance and B. Lactamase production in E. coli and Staphylococcus aureus". Ibn ALHaitham Journal for pure and Applied Science. 25(1).

Joshi, V., Joung, J.G., Fei, Z., \& Jander, G. 2010. "Interdependence of threonine, methionine and isoleucine metabolism in plants: accumulation and transcriptional regulation under abiotic stress". Amino Acids. 39(4), 933-947.

Kalefetoğlu, T., \& Ekmekçi, Y. 2005. "Bitkilerde kuraklık stresinin etkileri ve dayanıklılık". G. ̈. Fen Bilimleri Dergisi, 18(4), 723-740.,

Kwanyuen, P., \& Burton, J.W. 2010. "A Modified Amino Acid Analysis Using PITC Derivatization for Soybeans with Accurate Determination of Cysteine and Half-Cystine". Journal of the American Oil Chemists' Society 87(2), 127-132.

Miflin, B.J., Habash, D.Z. 2002. "The role of glutamine synthetase and glutamate dehydrogenase in nitrogen assimilation and possibilities for improvement in the nitrogen utilization of crops". Journal of Experimental Botany., 53(370), 979- 987.

Neuberg, M., Pavlikova, D., Pavlik, M., \& Balik, J. 2010. "The effect of different nitrogen nutrition on praline and asparagine content in plant". Plant Soil Environ, 56, 305-311.

O'Hara, C.M., Westbrook, G.L., \& Miller, J.M. 1997. "Evaluation of Vitek GNI+ and Becton Dickinson Microbiology Systems Crystal E/NF identification systems for identification of members of the family Enterobacteriaceae and other gram-negative, glucose-fermenting and non-glucose-fermenting bacilli". Journal of Clinical Microbiology, 35, 3269-3273.

Olgun, M., Budak Başçiftçi, Z., Ayter, N.G., Turan, M., Aydın, D., Şaban, Z., Ali Cevat Sönmez, A.C., Koyuncu. O. 2016. "Potasyum Iyodür Uygulamasının Ekmeklik Buğday Çeşitlerinin Biyokimyasal Özellikleri Üzerine Etkisi". Süleyman Demirel Üniversitesi Ziraat Fakültesi Dergisi 11 (2), 46-60,

Paschal, D., Burt, V., Caudill, S., Gunter, E. W., Pirkle, J.L., Sampson, E. J., Miller, D.T. \& Jackson, R.J. 2000. "Exposure of the US population aged 6 years and older to cadmium: 1988-1994". Archives of environmental contamination and toxicology, 38, 377-383. 
Paul, M.J., \& Driscoll, S.P. 1997. "Sugar repression of photosynthesis: the role of carbohydrates in signalling nitrogen deficiency through source: sink imbalance". Plant Cell Environx 20, 110-116.

Pavlíková, D., Pavlík, M., Staszková, L., Motyka, V., Száková, J., Tlustoš, P., \& Balík, J. 2008. "Glutamate kinase as a potential biomarker of heavy metal stress in plants". Ecotoxicology and Environmental Safety. 70(2), 223-230.

Puchenkova, S., 1996. "Enterobacteria in areas of water along the Crimean Coast". Mikrobiolohichnyi Zhurnal (Kiev, Ukraine: 1993), 58, 3-7.

Ros, R., Bertomeu, J.M., \& Krueger, S. 2014. "Serine in plants: biosynthesis, metabolism, and functions". Trends in Plant Science, 19(9), 564-569.

Sahiti, H., Bislimi, K., Rexhepi, A., \& Dalo, E. 2020. "Metal Accumulation and Effect of Vitamin $\mathrm{C}$ and $\mathrm{E}$ in Accumulated Heavy Metals in Different Tissues in Common Carp (Cyprinus carpio) Treated with Heavy Metals". Polish Journal of Environmental Studies. 29(1), 799-805.

Sanchez, F.J., Manzanares, M., Andres, E.F., Tenorio, J.L., \& Ayerbe, L. 1998. "Turgor maintenance, osmotic adjustment and soluble sugar and proline accumulation in 49 pea cultivars in response to water stress". Field Crops Res., 59, 225-235.

Singhl, B.K., \& Shaner, D.L. 1995. "Biosynthesis of branched chain amino acids: From test tube to field", The Plant Cell, 7, 935-944.

Tohge, T., Watanabe, M., Hoefgen, R., \& Fernie, A.R. 2013. "Shikimate and phenylalanine biosynthesis in the green lineage". Front Plant Sci., 4, 62.

Xu, J., Sun, J., Du, L., \& Liu, X. 2012a. "Comparative transcriptome analysis of cadmium responses in Solanum nigrum and Solanum torvum". New Phytol. 196(1), 110-124.

Yang, H.Q., \& Gao, H.J. 2007. "Physiological function of arginine and its metabolites in plants". Journal of Plant Physiology and Molecular Biology. 33(1), 1-8.

Wang, J., Chang, S., Chen, Y., \& Luh, K., 2000. "Comparison of antimicrobial susceptibility of Citrobacter freundii isolates in two different time periods". Journal of Microbiology, Immunology and Infection. 33, 258-262.

Wu, G. 2010. "Functional amino acids in growth, reproduction, and health". Advances in Nutrition, C 1, 31-37.

Wu, G. 2013. "Functional amino acids in nutrition and health", Amino Acids 45(3), 407-411. 
Zemanova' V, Pavlı'k M, Pavlı'kova' D. 2017. "Cadmium toxicity induced contrasting patterns of concentrations of free sarcosine, specific amino acids and selected microelements in two Noccaea species". Plos One 12(5), e0177963. 